\title{
ASSESSMENT DECISION MAKING IN VOCATIONAL EDUCATION AND TRAINING
}

\author{
HENNING FJØRTOFT, \\ ELIN BØ MORUD
}

\begin{abstract}
Assessment decision making is a highly contextual phenomenon. In this paper, we explore this topic in vocational education and training (VET). Thirty-eight teachers from five Norwegian upper secondary schools were interviewed before and after an 18-month research-practice partnership. To understand assessment decision making in VET, we draw on two bodies of knowledge: (a) research on teachers' decision making in assessment and (b) conceptualizations of teachers' professional capital. Four main findings emerged from the analysis: three assessment-related dilemmas and one professional capital-related dilemma. We then discuss how these aspects of practice affect assessment decision making and the implications for developing VET teachers' decisional capital.
\end{abstract}

\section{Keywords}

assessment, decision making, professional capital, vocational education, research-practice partnership 


\section{Introduction}

Assessment decision making in teaching has long been considered a complex phenomenon. Teacher assessment literacy has been conceptualized in several ways, but typically combines a knowledge base of discipline- and pedagogyrelated strands, the ability to make sound judgments about student learning processes and performances, and practical skills such as communicating assessment decisions (DeLuca \& Braund, 2019; Pastore \& Andrade, 2019; Willis et al., 2013; Xu \& Brown, 2016). However, assessment decision making is a highly contextual phenomenon. Xu and Brown (2016) emphasized the need to integrate sociocultural phenomena, such as policy, values, and social norms, into teachers' assessment literacy. Similarly, Willis et al. (2013) framed assessment decisions as part of a "dynamic, context dependent social practice" (p. 242) in which teachers negotiate curriculum elements, such as learning goals, with cultural knowledge of classroom phenomena.

The objective of this interview study is to explore assessment decision making in vocational education and training (VET). To understand this practice, we draw on two bodies of knowledge: (a) research on teachers' decision making in assessment and (b) professional capital. We then discuss how these aspects of practice affect assessment decision making and the implications for developing VET teachers' decisional capital.

\section{Theoretical Framework}

\section{Teachers' decision making in assessment}

Decisions are involved in all aspects of assessment, from design (Bearman et al., 2016; Boschman et al., 2014) to instructional decision making (Garner et al., 2017) to high-stakes assessment settings (Vanlommel \& Schildkamp, 2019). Several approaches to teaching, such as diagnostic testing, assessment for learning, and data use, involve decision making as a key component (Van der Kleij et al., 2015). Teachers use a broad set of evidence for decision making in the classroom, such as digital tests, homework assignments, oral tests, paper-and-pencil tests, portfolios, practical tasks, presentations, and questionnaires (Kippers et al., 2018). For example, in grading situations, teachers use a combination of (a) deliberately and systematically and (b) nondeliberately and nonsystematically collected data to make inferences about student learning (Vanlommel \& Schildkamp, 2019). A century of research on teachers' grading practices has shown not only that the meaning of grades has been hotly debated, but also that teacher assessment is able to capture multiple dimensions of student learning (Brookhart et al., 2016). 
Although some have argued that teachers primarily exercise judgment on an individual level in assessment situations (Kain, 1996), it is now common to consider teacher assessment practice as a situated phenomenon shaped by the collective practices of a community (Allal, 2013). For example, there are considerable national differences in teachers' approaches to assessment due to policy and testing frameworks; at the same time, there are differences at the microlevel between individual teachers' views on issues such as teacher professional autonomy and judgment or student agency and metacognition (DeLuca et al., 2021). Allal (2013) argued that although teacher judgment is subject to error and bias, it is similar to clinical judgment in the medical professions in that teacher judgment establishes a relationship between everything the evaluator knows about a particular individual and a wide array of knowledge, including explicit and tacit professional knowledge as well as institutional norms and rules. Therefore, learning how to make sound assessment-related decisions is not a simple procedural task but one of "earning foundational ideas and building an integrated stance toward teacher as assessor through contextualized reflective learning" (DeLuca \& Braund, 2019, p. 13)

Teachers' internal beliefs and values often clash with the pressures of external demands, creating tensions between the practicalities of classrooms and the rigorous application of measurement principles (McMillan, 2005). This suggests that teacher assessment decision making is affected in various ways by contextual factors such as policy and accountability frameworks, assessment practices (e.g., psychometric approaches, written essays, and performance assessments), and professional autonomy and judgment. Such contextual factors are likely to shape decision-making procedures for grading (e.g., the balance between analytical and holistic approaches to scoring, what counts as acceptable evidence of student learning, and the approaches to moderation used to ensure reliable results).

Tacit knowledge is important for skill development and has long been considered an important part of teachers' assessment literacy. Tacit knowledge is a crucial part of teachers' professional knowledge in feedback situations (Sadler, 1998), and scholars have argued that tacit knowledge is required if teachers are to provide students with meaningful knowledge of standards and criteria (O'Donovan et al., 2004). When making assessment decisions, teachers move back and forth between tacit and explicit knowledge (WyattSmith et al., 2010). In short, tacit knowledge constitutes a key component of assessment decision making, alongside numerical cut-offs, exemplars, and verbal descriptions (Sadler, 1987).

Recently, researchers have conceptualized teachers' decision making as two distinct processes: a rational process using purposively collected data and an intuition-driven process in which teachers process cues almost 
effortlessly and base their decisions on intuitive expertise and "feelings of knowing" (Vanlommel et al., 2017, p. 82). Navigating complex dilemmas to make decisions is a key part of this process (Xu \& Brown, 2016). If teachers' decision making relies on rational data-based processes and intuitive "knowing/feeling" processes (Vanlommel et al., 2017), then our current understanding of teachers' decision making must be further enriched by contextual studies exploring the interplay of knowing and feeling in assessment decision making. Therefore, we turn to the concept of professional capital as a way of framing our understanding of assessment decision making.

\section{Professional capital}

The concept of teachers' professional capital is a useful theoretical lens for understanding their assessment decision making. Professional capital is a conceptualization of teachers' professionalism that includes three aspects: human capital (individual talent), social capital (relational trust and collaborative capacity), and decisional capital (making good judgments with incomplete or conflicting evidence; Hargreaves \& Fullan, 2012). Without decisional capital, defined as the "ability to make discretionary judgements" (Hargreaves \& Fullan, 2012, p. 93), human capital and social capital are insufficient. However, because external factors, such as curricula, assessment policies, and governance structures, vary across boundaries, teachers' professional capital may take different forms in different contexts (Shirley, 2016).

In assessment contexts, decisional capital is important because the ability to make judgments is acquired by examining and comparing cases in structured and unstructured experience, practice, and reflection and is enhanced by drawing on colleagues' insights and experiences (Hargreaves \& Fullan, 2012). Unlike procedurally formed decisions, decisional capital cannot be based on fixed rules or incontrovertible evidence. Therefore, decisional capital is inherently social in that it rests on the accumulated experience of other professionals.

The components of assessment literacy do not have the same meaning or the same importance across contexts, and teachers must sometimes navigate competing assessment demands within their classrooms (Pastore \& Andrade, 2019). Given the dynamic and contextually sensitive nature of assessment practices (Willis et al., 2013), assessment decision making should be investigated across contextual and cultural borders so that our understanding of the phenomenon is enriched. For example, the competing narratives that teachers must manage in assessment decision making require teachers to navigate and adapt to complex situations (Bonner, 2016). Previous studies of teachers' intuitive decision making have been conducted in primary school settings (Vanlommel et al., 2017); research in upper secondary school settings is scarce. 
Assessment affects student learning, emotional well-being, and future opportunities in many ways. Although few studies have focused on teacher perceptions of grading, surveys have shown that teachers often include noncognitive and nonachievement factors such as effort or participation (McMillan, 2019). In some cases, decision making and responsibilities are subsumed under rational-legal forms of authority, increasing standardization of work procedures, and managerialism (Evetts, 2009). These issues are likely to converge in assessment dilemmas in which teachers must make decisions that impact student learning, well-being, or further career opportunities.

Professional capital among VET teachers is at least as complex as that of teachers in conventional academic subjects. In many countries, VET has traditionally focused on the acquisition of tacit knowledge and practical skills through hands-on experience (Lave \& Wenger, 1991; Sennett, 2008). However, in recent years, teachers have also been required to teach and assess students' basic, digital, and soft skills (Organisation for Economic Co-operation and Development [OECD], 2021). For example, career guidance is a social activity that requires collegiality, support, and trust from a range of stakeholders (Hearne \& Neary, 2021). However, it has been suggested that VET teachers are less likely to engage in deep collaboration that requires high levels of interdependence (Bükki \& Fehérvári, 2021). Therefore, efforts have been made to improve VET teacher collaboration, such as by using action research and professional learning community approaches (Andreasen \& Duch, 2020).

Drawing on Willis et al. (2013), we focused on VET teachers' need to negotiate the intersection of locally generated understandings of national policies, the teachers' learned knowledge of a discipline or vocation (e.g., mathematics or construction techniques), and their personal beliefs about learning and assessment as developed through experience. The following research question guided this study: What assessment dilemmas do VET teachers encounter, and how do these dilemmas affect the communities in which the teachers participate?

\section{Methods}

\section{Research design overview}

In this qualitative study, we explored assessment decision making in the VET context. To examine the phenomenon, we followed a pragmatist approach. As part of a larger research-practice partnership in upper secondary schools in Norway, we conducted semi-structured group interviews before and after an 18-month research-practice partnership. The study was informed in part by the theoretical framework outlined in the literature review section and in 
part by the researchers' experiences participating in research-practice partnership projects in VET. The present study is a secondary analysis focusing on assessment decision making in schools offering VET programs.

We concentrated on a group of teachers in schools offering vocational programs and the teachers' decision making in assessment situations. We explored the teachers' perceptions and experiences with decision making as part of the research-practice partnership.

\section{Study participants and data sources}

The Norwegian curriculum and assessment system is described in the national curriculum document. The curriculum document privileges disciplinary learning objectives (e.g., mathematics, literacy, and various vocational topics) and a broader human development perspective on values and principles (e.g., human dignity, ethical awareness, and democracy and citizenship) in an equal manner. Teacher assessment decision making plays a crucial part in this system. However, there are few guidelines for decision making, and the system, therefore, relies heavily on teacher professionality.

This study is a secondary analysis of data collected as part of a larger project involving 19 upper secondary schools and 12 university researchers collaborating to solve urgent problems of practice identified by the schools (Fjørtoft \& Sandvik, 2021). We selected data from five upper secondary schools offering one or more VET programs in the partnership. We excluded schools without VET programs and departments that offered tertiary vocational education (i.e., corresponding to higher engineering education). School leaders were asked to nominate interview participants based on a maximum variation strategy (i.e., both genders, varying levels of teaching experience, and a range of curriculum areas). Thirty-eight teachers from five Norwegian public upper secondary schools were selected by the principals. The teachers were interviewed during the 18-month research-practice partnership initiative (see Table 1 for details). The participants did not receive incentives for participating and were allowed to withdraw at any time during the interview process. 
Table 1

Interview Participants

\begin{tabular}{|c|c|c|c|c|c|c|c|}
\hline . & \multicolumn{6}{|c|}{ Participants: Teaching background, gender, and years of experience as a VET teacher } & 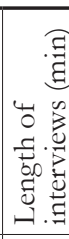 \\
\hline A & $\begin{array}{l}\text { Agronomy; } \\
\text { male; } 5 \text { years } \\
\text { of experience } \\
\text { (A1) }\end{array}$ & $\begin{array}{l}\text { Welding; } \\
\text { male; } 15 \text { years } \\
\text { of experience } \\
\text { (A2) }\end{array}$ & $\begin{array}{l}\text { Construction } \\
\text { techniques; } \\
\text { male; } 33 \text { years } \\
\text { of experience } \\
\text { (A3) }\end{array}$ & $\begin{array}{l}\text { Process tech- } \\
\text { nology; male; } \\
15 \text { years of } \\
\text { experience } \\
\text { (A4) }\end{array}$ & & & 103 \\
\hline A & $\begin{array}{l}\text { Healthcare; } \\
\text { female; } 9 \text { years } \\
\text { of experience } \\
\text { (A5) }\end{array}$ & $\begin{array}{l}\text { Nursing; } \\
\text { female; } 13 \text { years } \\
\text { of experience } \\
\text { (A6) }\end{array}$ & $\begin{array}{l}\text { Pre-school } \\
\text { education } \\
\text { and School } \\
\text { counseling; } \\
\text { female; } 15 \text { years } \\
\text { of experience } \\
\text { (A7) }\end{array}$ & $\begin{array}{l}\text { Nutrition and } \\
\text { health care; } \\
\text { female; } 35 \text { years } \\
\text { of experience } \\
\text { (A8) }\end{array}$ & & & 78 \\
\hline B & $\begin{array}{l}\text { Information } \\
\text { technology; } \\
\text { male; } 4 \text { years } \\
\text { of experience } \\
\text { (B1) }\end{array}$ & $\begin{array}{l}\text { Electrical } \\
\text { engineering; } \\
\text { male; } 7 \text { years } \\
\text { of experience } \\
\text { (B2) }\end{array}$ & $\begin{array}{l}\text { Language; } \\
\text { female; } \\
12 \text { years of } \\
\text { experience } \\
\text { (B3) }\end{array}$ & & & & 47 \\
\hline $\mathrm{C}$ & $\begin{array}{l}\text { Construction } \\
\text { techniques; } \\
\text { male; } 12 \text { years } \\
\text { of experience } \\
\text { (C1) }\end{array}$ & $\begin{array}{l}\text { Floral design; } \\
\text { female; } \\
29 \text { years of } \\
\text { experience } \\
\text { (C2) }\end{array}$ & $\begin{array}{l}\text { Gardening } \\
\text { and horticul- } \\
\text { ture; male; } \\
28 \text { years of } \\
\text { experience } \\
\text { (C3) }\end{array}$ & $\begin{array}{l}\text { Railway } \\
\text { engineering; } \\
\text { female; } 4 \text { years } \\
\text { of experience } \\
\text { (C4) }\end{array}$ & $\begin{array}{l}\text { Carpentry; } \\
\text { male; } 9 \text { years } \\
\text { of experience } \\
\text { (C5) }\end{array}$ & & 51 \\
\hline $\mathrm{D}$ & $\begin{array}{l}\text { Health care; } \\
\text { female; } 10 \text { years } \\
\text { of experience } \\
\text { (D1) }\end{array}$ & $\begin{array}{l}\text { Health care; } \\
\text { female; } 13 \text { years } \\
\text { of experience } \\
\text { (D2) }\end{array}$ & $\begin{array}{l}\text { Construction } \\
\text { techniques; } \\
\text { male; } 4 \text { years } \\
\text { of experience } \\
\text { (D3) }\end{array}$ & $\begin{array}{l}\text { Process } \\
\text { technology; } \\
\text { male; } 15 \text { years } \\
\text { of experience } \\
\text { (D4) }\end{array}$ & $\begin{array}{l}\text { Health care; } \\
\text { female; } 35 \text { years } \\
\text { of experience } \\
\text { (D5) }\end{array}$ & & 57 \\
\hline $\mathrm{E}$ & $\begin{array}{l}\text { Electrical } \\
\text { engineering; } \\
\text { male; } 4 \text { years } \\
\text { of experience } \\
\text { (E1) }\end{array}$ & $\begin{array}{l}\text { Skin care; } \\
\text { female; } 8 \text { years } \\
\text { of experience } \\
\text { (E2) }\end{array}$ & & & & & 35 \\
\hline $\mathrm{F}$ & $\begin{array}{l}\text { Social } \\
\text { science; male; } \\
25 \text { years of } \\
\text { experience } \\
\text { (F1) }\end{array}$ & $\begin{array}{l}\text { Agriculture; } \\
\text { male; } 25 \text { years } \\
\text { of experience } \\
\text { (F2) }\end{array}$ & $\begin{array}{l}\text { Agriculture; } \\
\text { female; } 5 \text { years } \\
\text { of experience } \\
\text { (F3) }\end{array}$ & $\begin{array}{l}\text { Landscaping; } \\
\text { female; } 5 \text { years } \\
\text { of experience } \\
(\mathrm{F} 4)\end{array}$ & $\begin{array}{l}\text { Gardening; } \\
\text { female; } 9 \text { years } \\
\text { of experience } \\
\text { (F5) }\end{array}$ & $\begin{array}{l}\text { Language; } \\
\text { female; } 8 \text { years } \\
\text { of experience } \\
\text { (F6) }\end{array}$ & 39 \\
\hline
\end{tabular}




\begin{tabular}{|c|c|c|c|c|}
\hline G & $\begin{array}{l}\text { Industrial } \\
\text { engineering; } \\
\text { male; } 15 \text { years } \\
\text { of experience } \\
\text { (G1) }\end{array}$ & $\begin{array}{l}\text { Language; } \\
\text { male; } 20 \text { years } \\
\text { of experience } \\
(\mathrm{G} 2)\end{array}$ & $\begin{array}{l}\text { Industrial } \\
\text { engineering; } \\
\text { male; } 7 \text { years } \\
\text { of experience } \\
\text { (G3) }\end{array}$ & 51 \\
\hline $\mathrm{G}$ & $\begin{array}{l}\text { Automation } \\
\text { and Electrical } \\
\text { engineering; } \\
\text { male; } 18 \text { years } \\
\text { of experience } \\
\text { (G4) }\end{array}$ & $\begin{array}{l}\text { Language; } \\
\text { female; } 12 \text { years } \\
\text { of experience } \\
\text { (G5) }\end{array}$ & $\begin{array}{l}\text { Automation } \\
\text { and Electrical } \\
\text { engineering; } \\
\text { male; } 7 \text { years } \\
\text { of experience } \\
\text { (G6) }\end{array}$ & 51 \\
\hline G & $\begin{array}{l}\text { Social } \\
\text { science and } \\
\text { Language; } \\
\text { male; } 39 \text { years } \\
\text { of experience } \\
\text { (G7) }\end{array}$ & $\begin{array}{l}\text { Physical edu- } \\
\text { cation and } \\
\text { Language; } \\
\text { male; } 8 \text { years } \\
\text { of experience } \\
\text { (G8) }\end{array}$ & $\begin{array}{l}\text { Restaurant } \\
\text { and Catering } \\
\text { services; female; } \\
20 \text { years of } \\
\text { experience } \\
\text { (G9) }\end{array}$ & 32 \\
\hline & \multicolumn{3}{|c|}{$\begin{array}{l}\text { The average length of experience is } 14.7 \text { years. } \\
\text { The median length of experience is } 12 \text { years. } \\
21 \text { were male, and } 17 \text { were female. }\end{array}$} & Total: $544 \mathrm{~min}$ \\
\hline
\end{tabular}

\section{Researcher positionality}

We participated in a team of researchers supporting the development of assessment literacy in upper secondary schools during a 5-year period. We were involved in data collection and the research-practice partnership with the schools. Each school received support for a minimum of 18 months. The data collection was approved by the Norwegian Centre for Research Data.

We were participant observers in at least one of the schools. We also met school leaders from all the schools at network meetings, and we frequently discussed teachers' and school leaders' efforts to improve assessment decision making. This allowed us to interpret the dataset in the context of teachers' daily practice.

\section{Data collection}

We conducted a secondary analysis of an existing set of interview data, including data collected by other researchers participating in the project. Four interviews were conducted by the research team before the researchpractice partnership took place, and six were conducted after it concluded. The interviews lasted between 32 and 103 min (mean duration 51 min). The questions were open to allow for teachers to express their reflections 
and experiences, and included probing for assessment dilemmas and compromises, how expectations were communicated to students, emotional issues related to assessment (for teachers, students, and school leaders), and teachers' assessment identities and conceptions of assessment literacy. For example, we asked teachers what kinds of decisions they made when assessing, what emotions were related to assessment, and how they viewed themselves as assessors. We audio-recorded the interviews using digital devices, transcribed the data verbatim, and selected a sample consisting of 10 group interviews with $2-6$ teachers per group ( $N=38$ teachers). We selected interviews with teachers working in the VET context.

\section{Analysis}

The first coding cycle was conducted using an inductive approach. We familiarized ourselves with the dataset, coded parts of the dataset, and discussed our coding approach collaboratively. This approach yielded a variety of codes related to the organization of the partnership and awareness of assessment-related issues. For example, teachers commented about resourcing and time allocation in the partnership. Teachers also discussed the process of becoming aware of the role of various assessment tools across situations or ensuring that students became aware of the role of self-assessment or peer assessment practices.

In the second coding cycle, we aggregated the codes by relating them to concepts drawn from literature regarding teachers' professional capital and assessment dilemmas or decision making. This body of literature is vast; therefore, we focused primarily on publications related to secondary education and VET. We followed the abductive approach, which meant that this process was reflexive, where the emerging codes were related to the literature and vice versa.

Choosing which inferences to follow is a key challenge in abductive analysis, as inferencing is a skill developed through acquiring ways of seeing and habits of thought (Tavory \& Timmermans, 2014, pp. 38-39). Our inferencing relied on our familiarity with secondary schools (both authors have worked as teachers), with research-practice partnership and partnership activities (both authors have extensive experience coordinating and participating in research-practice partnership initiatives), and with assessment research. For example, we identified several instances of teachers discussing dilemmas that arise in their decision-making practices. This led to reviewing the literature on dilemmas in assessment decision making and the role of dilemmas in professional capital. Consequently, our positioning as researchers led us to reflect on our multiple roles as scholars and educators in the partnership and to scrutinize our epistemological assumptions and theoretical lenses. 
We conducted the analysis individually and collaboratively; organized codes, categories, and samples from the dataset in spreadsheets; and crosschecked results in all stages until we reached agreement. This approach is similar to coding techniques where codes are considered open and fluid, and where the coding process is evolving and recursive; such approaches are considered interpretive and conceptual, reflecting the researchers' engagement with and interrogation of the data (Braun \& Clarke, 2021). For example, we combined the initial codes body language and specialist terms into a category called Communication and then conceptualized the codes as tensions between tacit and explicit knowledge. We resolved interpretive conflicts during each stage of analysis.

\section{Results and Interpretation}

Four main findings emerged from the analysis: three assessment-related dilemmas and one professional capital-related dilemma. The assessmentrelated dilemmas consisted of (a) tensions between tacit and explicit forms of knowledge; (b) tensions between curriculum objectives, business standards, and student ipsative goals; and (c) students at risk of failing. The professional capital-related dilemma was related to the interplay of assessment decisions and teachers' broader professional capital.

\section{Assessment-related dilemmas}

Tensions between tacit and explicit knowledge

Several dilemmas were related to tensions between tacit and explicit knowledge in VET settings. In some cases, this tension was related to justifying the assessment of students' behavior and social skills. Often, there was a discrepancy between the knowledge that students reproduced in assessment situations and students' behavior in professional settings. For example, some students performed poorly in their written responses but better in practice vocational contexts. Teachers described the dilemma of assessing students who behave in ways that contradict "what they write on paper" (A6) as challenging and noted "huge contrasts if you have a learning objective in relation to vocational behavior" (A8). Furthermore, teachers noted that students' use of mobile phones or cursing was unacceptable in some situations. We interpret this as an indication of the discrepancy between explicit and tacit knowledge in vocational settings.

We also found that the teachers talked about dilemmas connected to communication skills as part of vocational practice. For example, in healthcare vocations, students are expected to be able to communicate their theoretical understanding to teachers and to communicate with patients (e.g., older individuals, young children with minority language backgrounds, or patients 
who are hard of hearing). Furthermore, students in service industries are expected to communicate well with a range of customers and cater to their well-being and individual needs. This requires considerable tacit knowledge and situational awareness. The teachers commented that some students mastered communicating with patients well without being able to communicate professionally using specialist language. This situation constituted an assessment dilemma for the teachers: "Some students can be incredibly skilled at communicating... So, the question is how to assess [communicative] skills if the theoretical content is thin" (A8).

Furthermore, communicating about expectations was a challenge for teachers, especially when students had a poor understanding of the standards. One teacher described the discrepancy between students' and teachers' understanding in emotional terms:

Some might come to me saying, "I'm hoping for a 6" [the top grade]. And I've only had them for a month. And already I know that if we can get those students to achieve a 3 [midrange grade], then I'll be really happy. And it's hard to reach them. (A7)

In conclusion, there are considerable tensions between tacit and explicit knowledge in assessment decision making in VET. This tension affects and is affected by a range of other factors, such as communication, behavior, and standards.

Tensions between curriculum objectives, business standards, and student ipsative goals

Teachers reported experiencing a gap between the standards in the curriculum, expectations for vocational performance in businesses, and individual students' academic level. This led to teachers spending time uncovering students' existing knowledge and skills, inviting business representatives to the school to share their expectations, and emphasizing to the students the importance of meeting such expectations:

We have to assess them based on what we are teaching and what we have been through. We can't just go on and on teaching if they don't know anything - if nothing sticks. So, we have to figure out where they are in terms of the student and in terms of our teaching. (C3)

At Vg2 [the second year], I send them off for an apprenticeship period. They are learning construction work, and I have had people from the trade come to school several times. The business owners clarify what they envision in their employees. We are supposed to involve the private sector, right? So they come in and provide an idealized version. This provides a lot of guidance for how to behave for the students. (C3) 
VET $[. .$.$] is really an application process directed towards the business. That's$ when they get to show what they can do, so it's important that they are met in relation to the expectations there-becoming aware of being on time, being loyal, and doing what you're told. Those things are pretty specific. (C5)

However, this work was further complicated by the need to negotiate business standards and the needs of the student in some cases. Teachers sometimes asked students to focus on just a few curriculum objectives because the teachers knew that these objectives were more important in the business world. Formally speaking, this is in violation of the national curriculum, which states that students should master all domains in the curriculum. However, the teachers made such idiosyncratic decisions because they were familiar with the expectations in the business world. "I know what my colleagues expect from the students who leave school," a teacher (A6) commented, defending his choice to ignore certain parts of the curriculum in some cases.

Other teachers struggled to keep up with the dynamics of business standards. One teacher commented that he felt out of touch with the world of industrial practice after having worked as a VET teacher for more than a decade: "We've been in the school system for 10 to 15 years or more, so we find ourselves a little bit on the outside of society, so we've been isolated quite a while" (A4).

The teachers had developed a strategy for navigating this dilemma. For example, teachers mentioned using self-assessment and reflection exercises to prepare students for vocational standards. One teacher illustrated this practice with a perspective-taking activity in which the roles of the customer and the worker were reversed. The activity was coupled with reflection on professional standards and developing a sense of pride: "We're pushing professional pride a lot. What do you think the customer expects from a skilled worker?" (B2). This reversal of perspectives was intended to support students in understanding vocational performance from the perspective of clients and customers.

\section{Students at risk of failing}

Although national policies explicitly prohibit assessing student effort as part of the final grades, teachers felt that effort should be included as a mitigating factor for students at risk of failing. This seemed especially pronounced in borderline cases of passing or failing. A teacher (A3) said, "If they haven't shown up at school, or if I see that a student is unwilling or not trying, I would rather fail that student compared to others who show up at school and do their best." This practice is known as "pulling for students" (teachers want to give students the highest grades possible) and explains why nonachievement factors such as effort and improvement have been important 
in grading (Bonner, 2016). Several teachers reported experiencing emotional difficulties in making decisions in high-stakes situations carrying potentially grave consequences for the students: "I have strong feelings related to assessment ... A passing or nonpassing grade can have huge consequences for them" (A4). One teacher described losing sleep over grading and the process as "terribly painful" (A4). Another teacher reported similar experiences: "The worst time of the year is when you are assigning final grades because you are making decisions for the entire future of the students. So you're shaky all the time" (A8). One teacher discussed how decisions related to potentially failing at-risk students lead to increased teacher workload, deliberation with school leadership, and ultimately, negative consequences for students' potential opportunities:

I should have failed a student in science. But the student wanted to become a truck driver, so I gave him a 2 [lowest passing grade] so that he passed. Failing him in science would have meant a mountain of work for me. I discussed this with the school administration. And I had to see the bigger picture, too. He is working as a truck driver now and has a trade certificate. (A2)

These findings confirm that noncognitive aspects, such as emotions and intuition, impact teachers' decision making in VET. Furthermore, the findings suggest that teachers may struggle with specific motivations related to supporting students by "pulling” and that teachers use evidence of students' success after graduation to support their decision to do so.

\section{Professional capital-related dilemma}

The fourth dilemma was related to teachers' professional capital and their ability to use decisional capital in developing their assessment decision making. Several teachers commented that assessment was a socially situated practice and that shared understandings were required to maintain high levels of consistency: "We don't assess alone. We assess together with other teachers who share teaching interdisciplinary responsibilities" (C1). "Feedback and grading and assessment and all that ... It should be the same for all. There is a certain degree of discrepancy" (A2). However, some teachers resisted engaging in the community, a stance other teachers deemed unproductive. E2 said, "There are people in an organization who are not willing [to change] and who explicitly resist participating [in research-practice partnership activities]. They have a negative impact on group processes, frankly speaking."

The desire for improvement was evidenced in several statements and illustrates how teachers felt that the program was helpful in improving decision making. A teacher (G4) said, "You get a colleague who is more alert and forward-leaning. You don't lean back and say, 'The next 10 years I'm going 
to be a laidback teacher.' No, [I'm] forward-leaning and more focused on the student." Another teacher (D2) stated, "She [the principal] keeps saying that all the time. We are not stopping with [the project] now; we're going to continue what we're doing. I'm thinking there's a lot to be seen in relation to assessment."

However, in one school, teachers felt that the research-practice partnership program was too unstructured, and that clearer leadership was needed. A teacher (E2) stated, "Having a project where you are free to find your own line of inquiry is a good idea, but in our department, we would have benefited from a tighter style of leadership, providing more structure and supervision." The teachers at this school were less enthusiastic about the program and seemed to resist the opportunity to exercise professional autonomy. Thus, not all teachers chose to seize the opportunity to develop as practitioners.

\section{Discussion}

Teacher decision making is a rational and intuition-driven process (Vanlommel et al., 2017) and requires teachers to build an integrated stance through contextualized reflective learning (DeLuca \& Braund, 2019). If teachers in conventional academic subjects struggle to reconcile different aspects of the assessment system (Bonner, 2016), integrating rational and intuitive processes is likely to be even more challenging for VET teachers. In particular, discrepancies between school curricula, business standards, and student needs constitute threats to the integrity of assessment practices in VET. The present study showed that VET teachers face a range of dilemmas in their assessment decision making. Some dilemmas are well-known from previous literature, such as negotiating tensions between tacit and explicit dimensions of learning, students at risk of failing, and problems related to professional collaboration between teachers in assessment-related questions. Other dilemmas are specific to the nature of VET, such as tensions between different sets of goals (i.e., curriculum, business, and student goals).

In the remainder of this discussion, we focus on three aspects of assessment decision making in VET: decision making in high-stakes situations; discrepancies between curriculum, business standards, and student goals; and negotiating vocational learning and human development. We chose these aspects because they illustrate assessment dilemmas in VET contexts and how these dilemmas affect teacher communities.

First, in high-stakes situations, assessment decision making requires teachers to exercise judgment, especially in situations in which students may suffer dire consequences. McMillan (2019) suggested that teachers consider factors that have negatively influenced student achievement (e.g., illness) when 
making decisions in borderline cases, as well as tipping the balance toward higher grades when students show a clear learning progression. Although teachers' tendency to "pull for students" (wanting to give the highest grades possible) inevitably leads to questions of how decision making can be operationalized, as well as the fairness of using nonachievement factors such as effort or improvement in decision-making situations, idiosyncrasies may paradoxically lead to enhanced validity (McMillan, 2019). This recommendation is likely important for VET contexts, given the complexity of assessing the entirety of vocational knowledge and skills, as well as other cognitive and affective aspects of vocational learning. Adding the business sector as a third stakeholder in such attempts would involve stakeholders in setting standards and building tacit knowledge of vocational standards through shared experiences.

Second, although curriculum standards are stable and change only during periods of reform, vocational standards are less explicit and more dynamic, as illustrated by the interplay between the supply and demand of goods and services. For example, the transition from combustion to electric engines represented a paradigm shift in the world of mechanics. Consequently, VET teachers must negotiate a static (but explicit) curriculum and a dynamic and implicit set of standards in the world of business and commerce. The teachers must also prepare students to navigate the dynamics of the same sector. Lack of access or exposure to vocational communities may cause teachers' tacit knowledge to weaken and standards to concurrently shift. Discussing the role of tacit knowledge in assessment situations, Sadler (1987) suggested (a) sharing experiences through moderation attempts and (b) inviting students into such shared experiences to improve their understanding of criteria and standards. This could be achieved through dialogue, observation, practice, and imitation processes (O'Donovan et al., 2004) by which "exposure to other people's imaginations and strategies extends and enriches the teacher's repertoire of tactical moves" (Sadler, 1998, p. 81).

Third, the VET teachers in this study work in the Norwegian education system, which strives for a balance between employability (ensuring skilled workers) and a "whole student" philosophy. Therefore, assessment decision making must always negotiate the development of vocational skills with human development. The processes outlined in our discussion of high-stakes situations might also enable teachers to navigate this dilemma. Furthermore, teachers must also consider student ipsative goals as part of the larger human development process, including students in shared experiences of understanding standards and assessment criteria or making sense of teacher feedback. This is especially important if teachers are to provide students with feedback on their progression toward curriculum standards as well as the development of their character. 


\section{Limitations}

This study was based on a small sample size and focused primarily on teachers' self-reported practices and perceptions. Furthermore, the study was contextually limited to Norwegian schools, where teachers enjoy considerable professional autonomy. Therefore, because of the variety of structure and content in VET education internationally, the applicability of the findings to other contexts is limited. Further research, especially comparative and using different kinds of data, would expand the understanding of assessment decision making in VET represented in this study. In particular, extending the research to include the perceptions of students and businesses would enrich the perspectives.

\section{Implications}

Research on assessment literacy suggests that reflection on decision making and participation in community activities are two main ways for teacher learning to occur (Xu \& Brown, 2016). Encountering dilemmas in assessment practice (e.g., being confronted with ambiguous or conflicting evidence regarding a student's learning outcomes) may trigger teachers to seek additional information and reduce uncertainty (Allal, 2013). Although this shows that assessment decision making can be developed by reflecting on contextually relevant dilemmas, it is unlikely that VET teachers' decision making is improved solely by focusing on dilemmas alone. Hargreaves and Fullan (2012) pointed to the need for collective responsibility and external accountability in the teaching profession. Therefore, by situating researchpractice partnerships in the communities in which teachers work, and by reflecting on the specific dilemmas teachers encounter in their practice, teachers could develop their decisional capital using contextually relevant cases to build principles for sound judgment. This is especially relevant for VET, where tensions between tacit and explicit knowledge and different sets of standards in curricula and businesses shape teachers' decisions. However, the relation between collective responsibility and external accountability is also fraught in other areas of education. Therefore, dilemmas in assessment decision making should be considered as a threat to assessment integrity and as a potential source for teacher learning. 


\section{References}

Allal, L. (2013). Teachers' professional judgement in assessment: A cognitive act and a socially situated practice. Assessment in Education: Principles, Policy \& Practice, 20(1), 20-34. https:// doi.org/10.1080/0969594X.2012.736364

Andreasen, K. E., \& Duch, H. (2020). Teachers' professional development at VET Reflections on professional learning communities (PLCs). In C. Nägele, B. E. Stalder, $\&$ N. Kersh (Eds.), Trends in vocational education and training research, Vol. III. Proceedings of the European Conference on Educational Research (ECER), Vocational Education and Training Network (VETNET) (pp. 11-18). https://doi.org/10.5281/zenodo.3997331

Bearman, M., Dawson, P., Boud, D., Bennett, S., Hall, M., \& Molloy, E. (2016). Support for assessment practice: Developing the Assessment Design Decisions Framework. Teaching in Higher Education, 21(5), 545-556. https://doi.org/10.1080/13562517.2016.1160217

Bonner, S. M. (2016). Teacher perceptions about assessment: Competing narratives. In G. T. L. Brown \& L. R. Harris (Eds.), Handbook of buman and social conditions in assessment (1 $1^{\text {st }}$ ed., pp. 21-39). Routledge.

Boschman, F., McKenney, S., \& Voogt, J. (2014). Understanding decision making in teachers' curriculum design approaches. Educational Technology Research and Development, 62(4), 393-416. https://doi.org/10.1007/s11423-014-9341-x

Braun, V., \& Clarke, V. (2021). To saturate or not to saturate? Questioning data saturation as a useful concept for thematic analysis and sample-size rationales. Qualitative Research in Sport, Exercise and Health, 13(2), 201-216. https://doi.org/10.1080/2159676X.2019.1704846

Brookhart, S. M., Guskey, T. R., Bowers, A. J., McMillan, J. H., Smith, J. K., Smith, L. F., Stevens, M. T., \& Welsh, M. E. (2016). A century of grading research: Meaning and value in the most common educational measure. Review of Educational Research, 86(4), 803-848. https://doi.org/10.3102/0034654316672069

Bükki, E., \& Fehérvári, A. (2021). How do teachers collaborate in Hungarian VET schools? A quantitative study of forms, perceptions of impact and related individual and organisational factors. Empirical Research in Vocational Education and Training, 13(2), 1-26. https://doi. org/10.1186/s40461-020-00108-6

DeLuca, C., \& Braund, H. (2019, June 25). Preparing assessment literate teachers. Oxford research encyclopedia of education. Retrieved 2021, October 31 from https://oxfordre.com/ education/view/10.1093/acrefore/9780190264093.001.0001/acrefore-9780190264093-e-487

DeLuca, C., Rickey, N., \& Coombs, A. (2021). Exploring assessment across cultures: Teachers' approaches to assessment in the U.S., China, and Canada. Cogent Education, 8(1), 1921903. https://doi.org/10.1080/2331186X.2021.1921903

Evetts, J. (2009). The management of professionalism: A contemporary paradox. In S. Gewirtz, P. Mahony, I. Hextall, \& A. Cribb (Eds.), Changing teacher professionalism international trends, challenges, and ways forward ( $1^{\text {st }}$ ed., pp. 19-30). Routledge.

Fjørtoft, H., \& Sandvik, L. V. (2021). Leveraging situated strategies in research-practice partnerships: Participatory dialogue in a Norwegian school. Studies in Educational Evaluation, 70, 101063. https://doi.org/10.1016/j.stueduc.2021.101063

Garner, B., Thorne, J. K., \& Horn, I. S. (2017). Teachers interpreting data for instructional decisions: Where does equity come in? Journal of Educational Administration, 55(4), 407-426. https://doi.org/10.1108/JEA-09-2016-0106

Hargreaves, A., \& Fullan, M. (2012). Professional capital: Transforming teaching in every school (1 $1^{\text {st }} \mathrm{ed}$.). Teachers College Press. 
Hearne, L., \& Neary, S. (2021). Let's talk about career guidance in secondary schools! A consideration of the professional capital of school staff in Ireland and England. International Journal for Educational and Vocational Guidance, 21(2), 1-14. https://doi.org/10.1007/ s10775-020-09424-5

Kain, D. L. (1996). Looking beneath the surface: Teacher collaboration through the lens of grading practices. Teachers College Record, 97(4), 569-587. https://www.tcrecord.org/Content. asp?Content $\mathrm{Id}=1408$

Kippers, W. B., Wolterinck, C. H. D., Schildkamp, K., Poortman, C. L., \& Visscher, A. J. (2018). Teachers' views on the use of assessment for learning and data-based decision making in classroom practice. Teaching and Teacher Education, 75, 199-213. https://doi. org/10.1016/j.tate.2018.06.015

Lave, J., \& Wenger, E. (1991). Situated learning: Legitimate peripheral participation (1 ${ }^{\text {st }}$ ed.). Cambridge University Press.

McMillan, J. H. (2005). Secondary teachers' classroom assessment and grading practices. Educational Measurement: Issues and Practice, 20(1), 20-32. https://doi.org/10.1111/j.1745-3992.2001. tb00055.x

McMillan, J. H. (2019). Surveys of teachers' grading practices and perceptions. In T. R. Guskey \& S. M. Brookhart (Eds.), What we know about grading: What works, what doesn't, and what's next (pp. 84-112). ASCD.

O’Donovan, B., Price, M., \& Rust, C. (2004). Know what I mean? Enhancing student understanding of assessment standards and criteria. Teaching in Higher Education, 9(3), 325-335. https://doi.org/10.1080/1356251042000216642

OECD. (2021). Teachers and leaders in vocational education and training. OECD Reviews of vocational education and training. OECD Publishing. https://doi.org/10.1787/59d4fbb1-en

Pastore, S., \& Andrade, H. L. (2019). Teacher assessment literacy: A three-dimensional model. Teaching and Teacher Education, 84, 128-138. https://doi.org/10.1016/j.tate.2019.05.003

Sadler, D. R. (1987). Specifying and promulgating achievement standards. Oxford Review of Education, 13(2), 191-209. https://doi.org/10.1080/0305498870130207

Sadler, D. R. (1998). Formative assessment: Revisiting the territory. Assessment in Education: Principles, Policy \& Practice, 5(1), 77-84. https://doi.org/10.1080/0969595980050104

Sennett, R. (2008). The craftsman (1 ${ }^{\text {st }}$ ed.). Yale University Press.

Shirley, D. (2016). Three forms of professional capital: Systemic, social movement, and activist. Journal of Professional Capital and Community, 1(4), 302-320. https://doi.org/10.1108/JPCC08-2016-0020

Tavory, I., \& Timmermans, S. (2014). Abductive analysis: Theorizing qualitative research. University of Chicago Press.

Van der Kleij, F. M., Vermeulen, J. A., Schildkamp, K., \& Eggen, T. J. H. M. (2015). Integrating data-based decision making, Assessment for Learning and diagnostic testing in formative assessment. Assessment in Education: Principles, Policy \& Practice, 22(3), 324-343. https://doi. org/10.1080/0969594X.2014.999024

Vanlommel, K., \& Schildkamp, K. (2019). How do teachers make sense of data in the context of high-stakes decision making? American Educational Research Journal, 56(3), 792-821. https:// doi.org/10.3102/0002831218803891

Vanlommel, K., Van Gasse, R., Vanhoof, J., \& Van Petegem, P. (2017). Teachers' decisionmaking: Data based or intuition driven? International Journal of Educational Research, 83, 75-83. https://doi.org/10.1016/j.ijer.2017.02.013 
Willis, J., Adie, L., \& Klenowski, V. (2013). Conceptualising teachers' assessment literacies in an era of curriculum and assessment reform. The Australian Educational Researcher, 40(2), 241-256. https://doi.org/10.1007/s13384-013-0089-9

Wyatt-Smith, C., Klenowski, V., \& Gunn, S. (2010). The centrality of teachers' judgement practice in assessment: A study of standards in moderation. Assessment in Education: Principles, Policy \& Practice, 17(1), 59-75. https://doi.org/10.1080/09695940903565610

Xu, Y., \& Brown, G. T. L. (2016). Teacher assessment literacy in practice: A reconceptualization. Teaching and Teacher Education, 58, 149-162. https://doi.org/10.1016/j.tate.2016.05.010

\section{Corresponding authors}

\section{Henning Fjørtoft}

Department of Teacher Education, NTNU Norwegian University of Science and Technology, Trondheim, Norway

E-mail: henning.fjortoft@ntnu.no

\section{Elin Bø Morud}

Department of Teacher Education, NTNU Norwegian University of Science and Technology, Trondheim, Norway

E-mail: elin.morud@ntnu.no 
